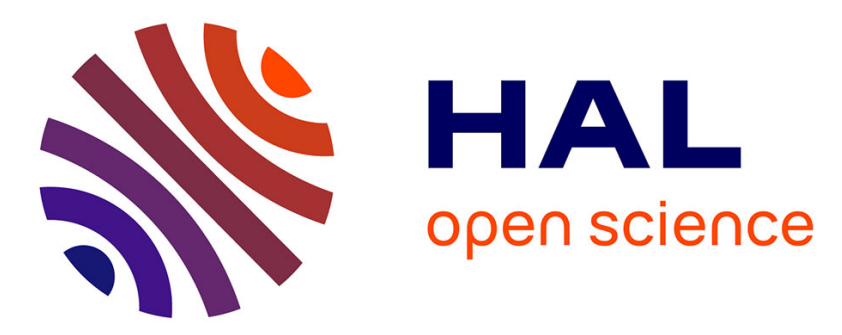

\title{
Seasonal to decadal scale shoreline changes along the Cameroonian coastline, Bay of Bonny (1986 to 2020)
}

Njutapvoui Nourdi, Onguene Raphael, Abessolo Grégoire, Rudant Jean Paul, Bogning Sakaros, Thomas Stieglitz, Tomedi Minette

\section{- To cite this version:}

Njutapvoui Nourdi, Onguene Raphael, Abessolo Grégoire, Rudant Jean Paul, Bogning Sakaros, et al. Seasonal to decadal scale shoreline changes along the Cameroonian coastline, Bay of Bonny (1986 to 2020). Regional Studies in Marine Science, 2021, 45, pp.101798. 10.1016/j.rsma.2021.101798 . ird-03219994

\section{HAL Id: ird-03219994 \\ https://hal.ird.fr/ird-03219994}

Submitted on 24 Nov 2021

HAL is a multi-disciplinary open access archive for the deposit and dissemination of scientific research documents, whether they are published or not. The documents may come from teaching and research institutions in France or abroad, or from public or private research centers.
L'archive ouverte pluridisciplinaire HAL, est destinée au dépôt et à la diffusion de documents scientifiques de niveau recherche, publiés ou non, émanant des établissements d'enseignement et de recherche français ou étrangers, des laboratoires publics ou privés. 


\section{Regional Studies in Marine Science}

\section{Seasonal to decadal scale wave induced shoreline changes along the Cameroonian coastline, Bay of Bonny (1986-2020) \\ --Manuscript Draft--}

\begin{tabular}{|c|c|}
\hline \multicolumn{2}{|l|}{ Manuscript Number: } \\
\hline Article Type: & Research Paper \\
\hline Keywords: & Coastline; wave climate; Bay of Bonny; optic; radar \\
\hline Corresponding Author: & $\begin{array}{l}\text { Nourdi Fokouop Njutapvoui, M.D. } \\
\text { Institute of Geological and Mining Research IRGM } \\
\text { Yaounde, Centre CAMEROON }\end{array}$ \\
\hline First Author: & Njutapvoui F. Nourdi, M.D. \\
\hline \multirow[t]{7}{*}{ Order of Authors: } & Njutapvoui F. Nourdi, M.D. \\
\hline & Onguéné Raphael, Dr \\
\hline & Abessolo O. Grégoire, Dr \\
\hline & Jean Paul Rudant, Pr \\
\hline & Sakaros Bogning, Dr \\
\hline & Thomas Stieglitz, Dr \\
\hline & Tomedi E. Minette, Pr \\
\hline Abstract: & $\begin{array}{l}\text { The Bay of Bonny along the Cameroon coastline is home to diverse ecosystems. It is } \\
\text { under substantial pressure from large human activity, but remains very little studied, } \\
\text { like much of the Gulf of Guinea. In order to understand its long-term shoreline } \\
\text { variations and the role the wave regime plays in the evolution of the coastline, a study } \\
\text { was conducted on the basis of optical image archives from Landsat } 5 / 7 / 8 \text { and Sentinel- } \\
\text { 2A/2B satellite missions acquired between October } 1986 \text { and May } 2020 \text {, coupled with } \\
\text { daily ERA-Interim wave re-analysis data covering the period from January } 1986 \text { to } \\
\text { August } 2019 \text {. Overall, the results show that the evolution of the coast is highly variable } \\
\text { in space and time, as indicated by different levels of erosion ( } 30.55 \% \text { ), and accretion } \\
\text { ( } 27.7 \% \text { ) on the decadal-scale, with the most significant variations occurring in } \\
\text { estuarine areas. Nevertheless, } 41.75 \% \text { of the Cameroon shoreline remains stable } \\
\text { during the study period. Three main periods during which the coast underwent } \\
\text { significant changes a different location were identified, reaching a retreat rate of up to - } \\
10 \text { m/year in the northern section during } 1986-1994 \text {. The wave regime decreases from } \\
\text { the southern part towards the north, with an annual trend of significant wave heights of } \\
\text { the five segments (-5.6 to -4.1 mm/year) with wave height maxima of } 1.46 \pm 0.65 \mathrm{~m} \\
\text { observed in the summer months (July-August). Monthly shoreline changes inversely } \\
\text { correlated with the wave climate in some segments but are in line with the seasonal } \\
\text { rhythm of the sub-region-s climate. The relatively strong local influence of erosion and } \\
\text { accretion caused by natural dynamics (waves, drift currents) associated with the } \\
\text { disproportionate presence of estuaries (Wouri, Rio del Rey, Sanaga) accounts for } \\
76.3 \% \text { of the observed variability, as indicated by analyses of eigenvalue orthogonal } \\
\text { decomposition (mode } 1 \text {, Empirical Orthogonal Functions). }\end{array}$ \\
\hline \multirow[t]{2}{*}{ Suggested Reviewers: } & $\begin{array}{l}\text { Dada A. Olusegun, Dr } \\
\text { Lecturer, Federal University of Technology, Akure | futa } \\
\text { oadada@futa.edu.ng } \\
\text { he is one of the greatest authors and specialist in coastal dynamics in the Bay of Biafra } \\
\text { area. }\end{array}$ \\
\hline & $\begin{array}{l}\text { Edward Anthony, Pr } \\
\text { European Center for Research and Education of Environmental Geosciences | } \\
\text { CEREGEAix-Marseille University } \\
\text { anthony@cerege.fr } \\
\text { He worked on several themes including Response of the coast of the Gulf of Benin } \\
\text { (Gulf of Guinea, West Africa) to anthropogenic and natural forcings. }\end{array}$ \\
\hline
\end{tabular}


Donatus Bapentire Angnuureng, Dr

Centre for Coastal Management, University of Cape Coast, Ghana donatus.angnuureng@ucc.edu.gh

Rafael Almar

Institut de recherche pour le developpement

rafael.almar@ird.fr 
August 17, 2020

\section{Editor of Regional Studies in Marine Science}

\section{Dear Editor of Regional Studies in Marine Science}

Please find enclosed our manuscript entitled "Seasonal to decadal scale wave induced shoreline changes along the Cameroonian coastline, Bay of Bonny (1986-2020)". It presents understanding of coastline dynamics on country scale, the aim of this work is to study coastline variations over the last 34 years (1986 to 2020) and the role of wave climate in coastal changes in Bonny Bay (Cameroonian coast). We would like to submit this study to your journal as a research paper. We hope it fits the scope of the journal.

We are looking forward to hearing from you.

Kind regards,

Njutapvoui F. Nourdi on behalf of all the co-authors. 
1

4 Sakaros Bogning2,5 ; Thomas Stieglitz ; Tomedi E. Minette ${ }^{6}$;

51 IRGM Institute of Geological and Mining Research; Vogt Street. BP: 4110 Yaoundé; Email:

6 njutapvouinourdi@yahoo.fr Phone: +237 6560549 14;

$7 \quad 2$ Young Team Associated with IRD Response of the Cameroonian Coast to Multi-Scale Ocean

8 Forcing (JEAI-RELIFOME), University of Douala, BP 24157 Douala, Cameroon;

9 ziongra@yahoo.fr

$10{ }^{3}$ LaSTIG/MATIS, Université Paris-Est, IGN, 5 Bd Descartes, Champs sur Marne, 77455 Marne

11 la Vallée CEDEX 2, France;rudant@univ-mlv.fr

124 Ecosystems and Fishery Resources Laboratory, Institute of Fisheries and Aquatic Sciences, 13 University of Douala, BP 2701 Douala, Cameroon.

145 Département de Sciences de la Terre, Université de Douala, BP 24157 Douala, Cameroun;

15 LEGOS Université de Toulouse, CNES, CNRS, IRD, UPS OMP, 14 Av. E. Belin, 31400 Toulouse,

16 France. Email: sakaros.bogning@legos.obs-mip.fr; Tel.: +33-561-332-970

$17{ }^{6}$ Marine Geophysical Laboratory, School of Mathematical and Physical Sciences, James Cook 18 University, Townsville QLD4811, Australia b Australian Institute of Marine Science, 19 Townsville QLD4810, Australia

20 Abstract

21 The Bay of Bonny along the Cameroon coastline is home to diverse ecosystems. It is under 22 substantial pressure from large human activity, but remains very little studied, like much of 23 the Gulf of Guinea. In order to understand its long-term shoreline variations and the role the 
24 wave regime plays in the evolution of the coastline, a study was conducted on the basis of

25 optical image archives from Landsat 5/7/8 and Sentinel-2A/2B satellite missions acquired

26 between October 1986 and May 2020, coupled with daily ERA-Interim wave re-analysis data

27 covering the period from January 1986 to August 2019. Overall, the results show that the

28 evolution of the coast is highly variable in space and time, as indicated by different levels of 29 erosion (30.55\%), and accretion (27.7 \%) on the decadal-scale, with the most significant 30 variations occurring in estuarine areas. Nevertheless, $41.75 \%$ of the Cameroon shoreline 31 remains stable during the study period. Three main periods during which the coast 32 underwent significant changes a different location were identified, reaching a retreat rate of

34 from the southern part towards the north, with an annual trend of significant wave heights 35 of the five segments ( -5.6 to $-4.1 \mathrm{~mm} / \mathrm{year}$ ) with wave height maxima of $1.46 \pm 0.65 \mathrm{~m}$ 36 observed in the summer months (July-August). Monthly shoreline changes inversely 37 correlated with the wave climate in some segments but are in line with the seasonal rhythm 38 of the sub-region-s climate. The relatively strong local influence of erosion and accretion 39 caused by natural dynamics (waves, drift currents) associated with the disproportionate 40 presence of estuaries (Wouri, Rio del Rey, Sanaga) accounts for 76.3\% of the observed 41 variability, as indicated by analyses of eigenvalue orthogonal decomposition (mode 1 , 42 Empirical Orthogonal Functions). These characteristics explain a complex pattern of 43 coastline changes with an almost continuous retreat shoreline during the period 1986-2012 44 and a reversal in trend towards accretion during the period 2012-2020. EOF mode 2 explains $4523.7 \%$ of variability associated with the gradual overall decline from south to north over the 46 study period. This is attributed to an overall decrease in the supply of sediment via the 47 coastal transport system that prevails in the Gulf of Guinea. 
48 Key words: Coastline, wave climate, Bay of Bonny, optic, radar

\section{Introduction}

Coastal areas around the world are increasingly anthropized and inhabited because of their socio-economic and recreational importance (Boateng, 2009, 2012). Several recent studies (Luijendijk et al., 2018; Kuenzer et al., 2014; Dada et al., 2015, 2016) have shown that these environments are also subject to varying degrees of natural and anthropogenic morphological variation, thereby increasing the vulnerability of these areas and the risks to property and people (Richards and Nichols, 2009). The very high vulnerability of some coastal environments remains a major concern (Bosom and Jiménez, 2011; Tano et al. 2016) in view of the intensification of extreme wave and tidal events and sea level rise due to climate change (Pilkey and Cooper, 2014; Ranasinghe, 2016; Anthony, 2017). Tropical coastal environments are particularly affected by erosion and flooding, but their variability and vulnerability is still poorly understood, especially on long time scales (decades), due to the lack of adequate morphological and hydrodynamic data. Coastal management policies in these regions are, more often than not, limited to local scale and not well informed to support sustainable coastal development on a large spatial scale.

In West Africa, studies have been carried out on coastal zone dynamics to assess its vulnerability. Almar et al (2014) demonstrated the importance of understanding the causes of erosion observed in the Bay of Benin on several scales, and Laibi et al. (2014) demonstrated the impact of the presence of ports and coastal infrastructures. The work of Dada et al. 2016 has led to an understanding of the wave climate, its potential changes and its implications on coastal evolution for environmental monitoring and sustainable management of the Niger Delta. In addition, several major projects have been launched in West Africa, including the West African Coastal Observation Mission (MOLOA, 2013), aimed 
72 at an integrated coastline management strategy, including the production of historical data

73 on coastal dynamics and risks in coastal areas. Giardino et al. 2018 proposed a large-scale

74 coastal policy for the development of sustainable management practices in coastal areas, but

75 this is difficult to implement.

76 Along the Cameroon coastline, few studies have been carried out on coastal dynamics.

77 Abessolo et al. 2018 have studied coastal erosion/accretion processes through the modelling 78 of barotropic currents in the Wouri estuaries in central Cameroon. The recent work of Fotsi 79 et al. 2019 on the temporal (1948-2012) and dynamic evolution of the Wouri estuary's 80 coastline have demonstrated the influence of the sedimentary regime on the variation of its 81 coastline. These works have shown that the Cameroonian coastline has undergone complex 82 patterns of shoreline modification. However, regional-scale sustainable coastal zone 83 management is hampered by a general lack of continuous and accurate historical data on the 84 position of the coastline. It is difficult to study the impact of hydrodynamic forcing on the 85 Cameroonian coastline due to the lack of morphological data. More importantly, the multi86 scale nature of wave impact: event-driven (impact of storms and waves, and tides); seasonal 87 (seasonal behaviour of the coastline); interannual to decadal trend (difficult to observe due 88 to lack of adequate data) remains almost unknown on this coast.

90 scale, the aim of this work is to study coastline variations over the last 34 years (1986 to

912020 ) and the role of wave climate in coastal changes in Bonny Bay (Cameroonian coast).

2. Materials and Methods

94 The study area is located between Rio-del-Rey (Cameroon) to Campo (Equatorial 95 Guinea) and covers entire Cameroonian coastline in the Bay of Biafra (Fig. 1). This coast is 
96 characterized by different ecosystems. Ten major rivers flow into the ocean, the most

97 important of which are Ntem, Nyong, Sanaga, Wouri and the Rio del rey. Following Giresse

98 et al. (1996) four subsets (S-E) of the coast were defined (Fig. 1), as follows:

99 - Subset 1: Composed of the Rio del rey and Cross river basins bordering the east of the Bakassi 100 peninsula in Cameroon, this complex is considered as an extension of the eastern zone of the 101 Niger delta set up during the Paleocene-Eocene. It contains the largest zone of mangroves $102(125,259$ hectares) in the country (Ajonina, 2010; MINEPDED-RCM, 2017) and a group of 103 islets. The Rio del Rey's estuary is open and shallow, with tidal amplitudes reaching up to 3 $104 \mathrm{~m}$. 105 - Sub-group 2 (Idenau to Limbé): This section is characterized by small basalt cliffs separated 106 by small bays with pebble and sand beaches on the volcanic base of Mount Cameroon.

107 - Subset 3 (Cameroon estuary): with an area of 103,817 ha (ONEQUIP, 2009), it constitutes a 108 vast wetland, $30 \mathrm{~km}$ long and almost as wide; it is an integral part of the Wouri watershed. 109 The relief is formed by a succession of sedimentary plains. This bay is also bordered by the 110 second largest mangrove area (93,549 hectares) (MINEPDED-RCM, 2017), and is the 111 receptacle of the main rivers of the region (Wouri, Mungo and Dibamba). The average tidal 112 range is $2 \mathrm{~m}$ with maximum reaching $3 \mathrm{~m}$ in fast flowing waters. (Onguéné et al., 2015).

113 - Subset 4 (Kribi-Campo): From the mouth of the Nyong to the Ntem River, this coast is 114 characterized by the presence of sandy beaches, which alternate with rocky headlands, 115 lagoons, mangroves and other coastal vegetation. It contains two protected areas (Douala116 Edea Wildlife Reserve and Campo-Ma'an National Park). The tidal range is about $1.8 \mathrm{~m}$ at 
117 Campo, $1.5 \mathrm{~m}$ at Kribi and $1.2 \mathrm{~m}$ at Petit-Batanga. (Giresse et al., 1996).

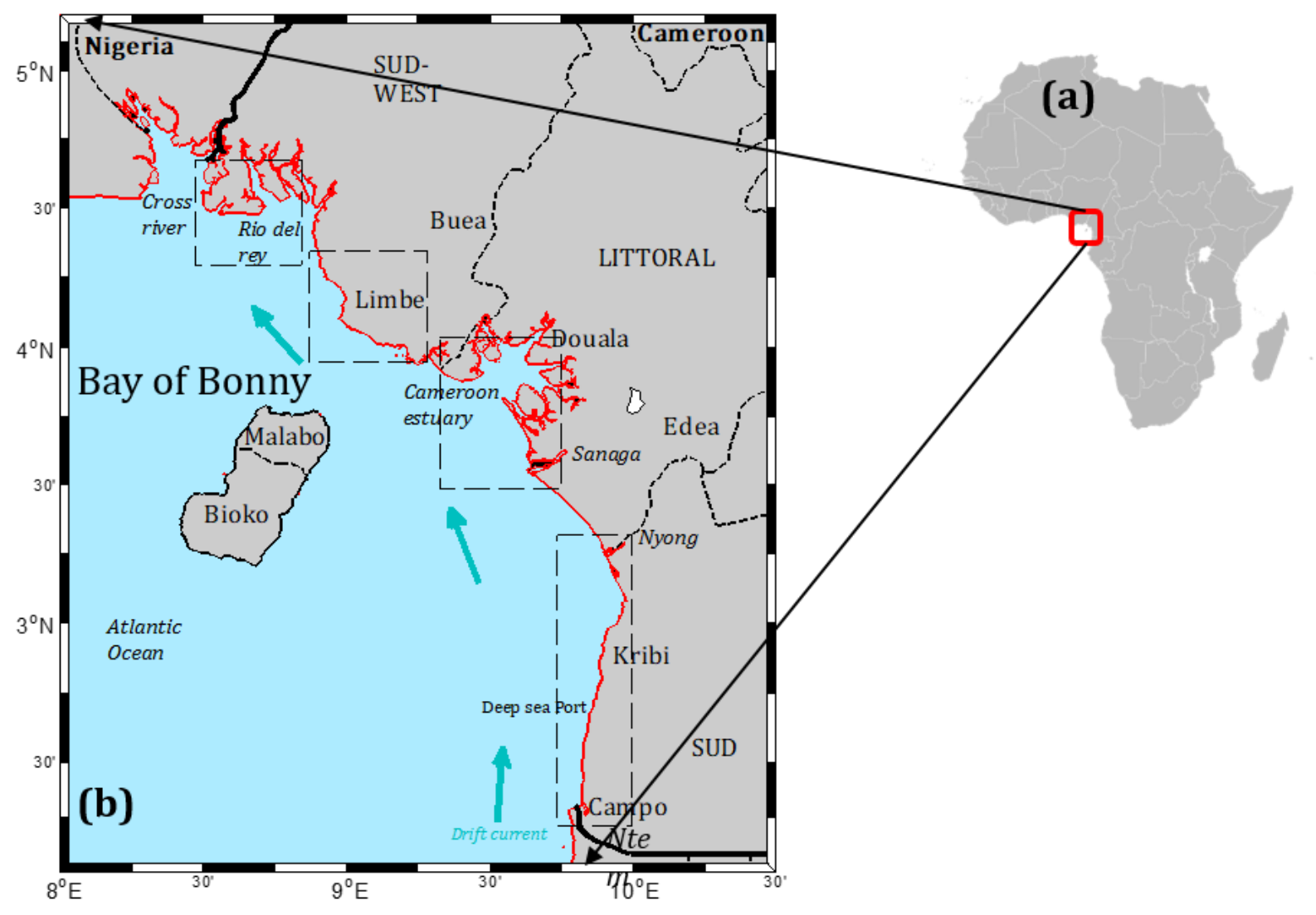

Figure 1: The coast of Cameroon in Bay of Bonny. The study area extends from the mouth of the Ntem (border with Equatorial Guinea to the south) to the Rio del Rey at the Nigerian border. This mesotidal coast is dominated by waves and regional current that generate a strong S-SW longshore drift. The three main cities of the coast, Kribi, Douala and Limbe, are each presented in the figure $b$.

\subsection{Landsat and Sentinel-2 Image Extraction and Processing Under DSAS}

We extracted a set of 10 images with less than 10\% cloud cover (a common problem in the tropics), i.e. 7 images from Landsat 5/7/8 missions downloaded from earthexplorer.usgs.gov and 3 images from the Sentinel 2A/2B satellites downloaded from the Copernicus platform (https://scihub.copernicus.eu/dhus/) of the ESA (European Space Agency). All Landsat satellites are orbiting at an altitude of $705 \mathrm{~km}$ with a swath of $185 \mathrm{~km}$ / 185 km (Fernand, 2002). The "Sentinel-2" constellation, on the other hand, consists of two 
131 satellites (Sentinel-2A and Sentinel-2B), at an altitude of $786 \mathrm{~km}$ and a swath of 250/250 km.

132 Orbiting on the same sun-synchronous trajectory, but with a phase shift of $180^{\circ}$ with respect

133 to each other. The revisit time is 10 days for each satellite (Tab. 1), which corresponds to 5 134 days for the couple S-2A and S2-B. A summary of the different characteristics of the images 135 is given in Table 1.

136 Table 1: Summary of the satellite images used in this study.

\begin{tabular}{|c|c|c|c|c|c|c|}
\hline $\begin{array}{l}\text { Satellite } \\
\text { Mission }\end{array}$ & sensors & Revisit period & Pixel size and band used & $\begin{array}{c}\text { Acquisition } \\
\text { date } \\
\text { (yyyy/mm/dd) }\end{array}$ & $\begin{array}{c}\text { Cloud } \\
\text { cover }(\%)\end{array}$ & $\begin{array}{c}\text { Number of } \\
\text { images }\end{array}$ \\
\hline Landsat 5 & $\mathrm{TM}$ & & $\begin{array}{c}30 \text { m, Bands: R (B3), G (B2), B (B1) } \\
\text { NIR (B4), SWIR1 (B5, B7) }\end{array}$ & $1986 / 01 / 26$ & 3.6 & 1 \\
\hline Landsat 7 & ETM+ & 16 days & $\begin{array}{l}30 \text { m, Bands: R (B3), G (B2), B (B1) } \\
\text { NIR (B4), SWIR1 (B5, B7) } \\
\text { +15 m panchromatic band }\end{array}$ & $\begin{array}{l}1999 / 12 / 17 \\
2005 / 03 / 27 \\
2010 / 02 / 14\end{array}$ & $\begin{array}{c}2.4 \\
6.2 \\
1.24\end{array}$ & 3 \\
\hline Landsat 8 & OLI & & $\begin{array}{l}30 \text { m, Bands: R (B3), G (B2), B (B1) } \\
\text { NIR (B4), SWIR1 (B5, B7) } \\
+15 \text { m panchromatic band }\end{array}$ & $\begin{array}{l}2013 / 12 / 22 \\
2016 / 03 / 27 \\
2018 / 02 / 03\end{array}$ & $\begin{array}{l}5.14 \\
1.33 \\
6.31\end{array}$ & 3 \\
\hline $\begin{array}{l}\text { Sentinel } \\
2 \mathrm{~A} / 2 \mathrm{~B}\end{array}$ & MSI & $\begin{array}{l}5 \text { days (Couple } \\
\text { S-2A and S-2B) }\end{array}$ & $\begin{array}{l}10 \text { m Bands: R(B4), G(B3), B(B2) NIR } \\
\text { (B8) +20 m SWIR1 (B12, B11) }\end{array}$ & $\begin{array}{l}2015 / 11 / 29 \\
2017 / 05 / 07 \\
2020 / 05 / 26\end{array}$ & $\begin{array}{c}5 \\
2.42 \\
0.97\end{array}$ & 3 \\
\hline
\end{tabular}

TM (Thematic Mapper), ETM+ (Enhanced Thematic Mapper), OLI (Operational Land Imager), MSI (Multi-spectral instrument); R: red, G: green, B: blue, NIR: near infrared, SWIR: short wave infrared. B1-B12: spectral bands.

A series of digital pre-processing was carried out on all the images, ranging from georeferencing, resetting the images of the various sensors, atmospheric and radiometric correction, contrast enhancement, and the application of a cloud mask to eliminate all images that exceed a certain percentage of cloud cover (include a reference that describes this approach). The quality of the satellite images was improved to obtain optimal detection of the coastline by pan-sharpening (combining the visible band (30 $\mathrm{m}$ for Landsat and $10 \mathrm{~m}$ for Sentinel 2) with the panchromatic band (15 $\mathrm{m}$ for Landsat and $10 \mathrm{~m}$ for Sentinel). After this step, all bands were reduced to 15 and $10 \mathrm{~m}$ for the pixel size of Landsat $7 \& 8$ and Sentinel 
2A/B respectively, in order to obtain images with better image quality while decreasing as much as possible the digital precision error.

Subsequently, image mosaics were created in order to obtain overall images of the study area. A coloured composition of the bands of each sensor was performed (Tab. 1 column 3), in order to choose the most appropriate channel to extract the indicator used as a coastline marker (Robin, 2002). Classically, shoreline detection is carried out either in the near infrared or mid-infrared due to the low reflectance of water in the infrared range of the electromagnetic spectrum. On this basis, in order to best highlight the contact between the dry sediments of the high beach and the vegetation cover a coloured composition of the spectral bands was therefore used to discriminate the high beach/vegetation interface (Robin, 2002).

To calculate and map the overall coastline displacement rate, the Digital Shoreline Analysis System (DSAS) plug-in version 4.3 (Thieler et al., 2009), in ArcMap software, shoreline detection and extraction was performed manually by scanning the visible vegetation line and using 1986 as the baseline, the rates of shoreline change for 1999, 2005, 2010, 2013, 2015, 2016, 2017, 2018, and 2020 were calculated. All extracted coastlines were projected to the World Geodetic System UTM 32N reference system (WGS 84). After selecting the 1986 reference line (baseline), the transects were projected from this line at $500 \mathrm{~m}$ intervals which intercepted each coastline initially vectorised. The Net Shoreline Motion (NSM) and End Point Rate (EPR) statistics incorporated in DSAS were calculated to estimate the shoreline variation for the entire study period. We also specified for each coastline a global uncertainty value $(+/-15 \mathrm{~m})$ which accounts for the positional and measurement uncertainties. 


\subsection{Landsat and Sentinel-2 image extraction and processing with the CoastSat Toolbox}

In order to obtain a longer and less constraining time series, to study the across-shore variability of the coastline, we used a stack of 425 images retrieved from the Google Earth Engine (GEE) platform via the open-source CoastSat toolkit (Python version 3.6), that allowed us to obtain time series of shoreline position with a horizontal accuracy of $10 \mathrm{~m}$ any sandy coastline worldwide (Vos et al., 2019). This algorithm allows to retrieve TOA (Top-ofAtmosphere) reflectance images from the GEE archives of Landsat 5/7/8 and Sentinel-2 satellites; and subsequently perform pre-processing of multi-spectral images (cloud masking, pan-sharpening, classification) as described in (Vos et al., 2019). Unlike DSAS, the Coastsat toolbox performs an automatic extraction from a single reference line (baseline) digitized by the user. It then generates the line for each of the sub-pixel resolution images (van der Walt et al., 2014). However, the results only become usable after applying a tidal correction (Eq. 2), which is not implemented in the toolbox as it is specific to each area (Vos et al, 2019). The user has the option of choosing a profile in which the time series of the crosshore distance along the user-defined normal coastal transects is generated.

\subsection{Estimation of errors associated with the position of the coastline}

To constrain coastline change rates, we estimated four sources of error based on the method of Hapke et al. 2010, i.e. uncertainties associated with georeferencing, digitization, satellite position and tidal water level uncertainty. The mean values for each uncertainty term are presented in Table 2.

The error in digitizing the coastline depends on several factors including the quality of the reference data; the accuracy of the digitization (operator application); the expertise of the operator in interpreting the reference data. 
195 Following Moore and Griggs (2002), the total error related to digitizing (Eq. 1) can be 196 estimated by the sum of the mean $(\bar{X})$ of the offsets recorded during the repetition of the digitization and 2 standard deviations $(2 \sigma)$ :

$$
\text { - } \quad E_{d}=\bar{X}+2 \sigma
$$

199 To obtain the errors related to tidal sea level oscillations, it is recommended that along coasts 200 with large tidal ranges and/or flatter beach profiles, all shorelines be adjusted to a standard reference elevation (Stafford and Langfelder, 1971). Since all images are acquired between 09:00 and 10:00 local time, but at different stages of the tide, a linear tidal correction can be applied using the measured water levels and the characteristic beach slope to translate each shoreline into a reference elevation as follows:

$$
E_{t}=\frac{\left(Z_{r e f}-Z_{w l}\right)}{\tan \beta}
$$

$206 E_{t}$ is the horizontal offset across the normal transect to the coast, $Z_{r e f}$ is the reference 207 elevation (e.g. $0 \mathrm{~m}$ above mean sea level) and $Z_{w i}$ is the local water level at the time of image 208 acquisition, and $\tan \beta$ is the beach slope. The precise time of image acquisition to obtain the 209 local water level is stored in the image metadata.

210 Field work carried out on the beaches of the southern part of Cameroon (Kribi) showed 211 that the typical average slope $\tan \beta$ is 0.57 or $(5.7 \%)$. The significant wave height (Hs) 212 provided by ERA-Interim shows an overall average of $1.04 \mathrm{~m}$ off the coast. Tide levels remain 213 relatively low $(\leq 2 \mathrm{~m})$. Thus, for example, the Landsat 8 image of 06 June 2013 was recorded 214 at $09 \mathrm{~h} 41 \mathrm{~min}$ coinciding with a tidal level of $0.4 \mathrm{~m}$. The error (Eq.3) is considered here as 215 the sum of the squares of the different sources of error mentioned above:

$$
E_{i}=E_{g}^{2}+E_{t}^{2}+E_{d}^{2}+E_{p}^{2} \quad \text { (3) ; } E_{i} \text { error of time period } \mathrm{i}\{1,2, \ldots \ldots \mathrm{n}\}
$$




\begin{tabular}{cccccc}
\hline Measurement errors & \multicolumn{5}{c}{ Uncertainty (m) 1986-2020 } \\
& Landsat 5 & Landsat 7 & Landsat 8 & Sentilnel 2 & \\
\hline Georeferencing error (Eg) & 5 & 2.5 & 2.5 & 1 & \\
Digitizing error (Ed) & \pm 1.5 & 1.05 & 1.05 & 0.7 & \\
Tide error (Et) & $/$ & 5.24 & 4.28 & 2.04 & \\
Pixel size error (Ep) & 30 & 15 & 15 & 10 & 0.16 \\
\hline \multicolumn{5}{c}{ Totat shoreline position error (ET) } \\
\hline
\end{tabular}

\subsection{In-situ data and processing}

Given the near absence of field data on the coast, daily topographic survey campaigns 223 using theodolite and GPS were carried out between 09-30 April 2018 in the Kribi area (C5), 224 and between 13-31 May 2019 for the Limbé area (C2). Data was recorded at low tide in order 225 to set the reference height $\mathrm{Z}=0$ with respect to the mean sea level. We performed a resetting 226 and georeferencing in a Mercator WGS84 projection system with an absolute planimetric 227 accuracy of less than $5 \mathrm{~m}$. This was done in order to bring all the data into the same 228 geographic coordinate system as the satellite data. An instantaneous long-shore and cross229 shore average over a $100 \mathrm{~m}$ interval was necessary to reduce the error of the coastline 230 position during the survey.

\section{2.6. Extraction and processing of Era-Interim wave data}

Wave parameters (significant height Hs, period Tp and direction) were extracted from 233 the server of the European Centre for Medium-Range Weather Forecasts (ECMWF/ECMWF 
https://apps.ecmwf.int/datasets/data/interim-full-daily/) on a $0.125^{\circ}$ x $0.125^{\circ}$ grid, with a time delay of one day resolution, from January 1986 to August 2019. These data are part of the ERA-Interim dataset from the Ers-1\&2, Envisat, Jason-1\&2 altimetry missions, which involves the analyses of global meteorological variables (Dee et al., 2011; Sterl and Caires, 2005). These data have been widely validated against buoys and altimetry data (Sterl and Caires, 2005), with maximum wave height (Hs $>5 \mathrm{~m})$ and minimum wave height $(\mathrm{Hs}<1 \mathrm{~m})$ tending to be under and overestimated respectively (Caires, Swail and Wang., 2006). Fortunately, extreme wave conditions are generally not observed in the relatively constant wave regime in the Gulf of Guinea.

We extracted the time series of Hs for the grid points closest to the coast and then used time averages of the wave parameters for each segment ( $\mathrm{C} 1$ to $\mathrm{C} 5$ ) over a period of 33 years. However, as larges do not reach the Cameroonian coast, we used the formula proposed by Larson et al in 2010 (Eq. 5) to calculate Hs, Tp and direction at the closest grid point to the 247 coast. This method has been validated by the properties of deep-water waves (Larson et al., 248 2010).

$249 h_{b}=\left(\lambda c^{2}\right) / g$

$250 \alpha_{b}=\operatorname{asin}\left(\sin \left(\alpha_{0} \sqrt{\lambda}\right)\right)$

$251 \quad \operatorname{Avec} \lambda=\Delta \lambda_{a} ;$ considering

$252 \Delta=1+0.1649 \xi+0.5948 \xi^{2}-1.6787 \xi^{3}+2.8573 \xi^{4}$

$253 \xi=\lambda_{a} \sin \theta_{0}^{2} ; \lambda_{a}=\left[\cos \left(\alpha_{0}\right) / \theta\right]^{2 / 5} ; \quad \theta=\left(\frac{c}{\sqrt{g H}}\right)^{4}\left(\frac{c}{c_{g}}\right) \gamma^{2}$

254 hb wave height at wave break; T period (does not change as it propagates from the open sea 255 to the coast); $\gamma=h_{b} / H$ wave breaking threshold following Battjes and Janssen (1978) $\mathrm{H}$ 
depth at the point of wave breaking, and finally $C_{g}=c / 2$ the group velocity of waves propagating towards the coast and $\theta_{0}$ and $\theta$ direction of waves in deep water and at the point of wave breaking respectively.

We averaged each series of data (coastline and Hs) on a monthly basis for each segment. Subsequently, a mean value was calculated and subtracted from each value in the data series. Seasonal signal were removed, using a least square fit to the sine functions, before calculating trends. The trend calculation was based on a simple linear regression fit.

$$
\text { - } f(x)=a_{n} * \sin \left(b_{n} * x+c_{n}\right) \quad n \in \mathrm{N}
$$

With a amplitude; b angular speed and c the phase shift.

\section{Results}

\section{$266 \quad 3.1$ Coastal changes from 1986 to 2020}

DSAS analyses indicate that $30.55 \%$ of Cameroon's shoreline are eroding, $27.70 \%$ are 268 accreting and $41.75 \%$ are stable. Figure 2c illustrates the longshore variation of the coastline 269 during the period 1986 to 2020 following a period marked by deep and permanent changes 270 in the estuaries (C1 and C3) of the Rio del Rey and Wouri estuaries respectively. Some areas 271 were found to be stable (C2, Limbe), and some areas with small-scale shoreline changes were 272 identified. e.g. C5 (Kribi Coast) with erosion and deposition rates ranging between -2.7 and $2732.1 \mathrm{~m} / \mathrm{year}$, and only a minor displacement of the shoreline of $10 \mathrm{~m}$ between 2008 and 2013 274 observed on the northern coast of Kribi (Fig.2a). The maximum observed erosion occurred 275 at Rio del rey and Cap Cameroon (C3) with significant shoreline retreats of up to -19.2 /year. 

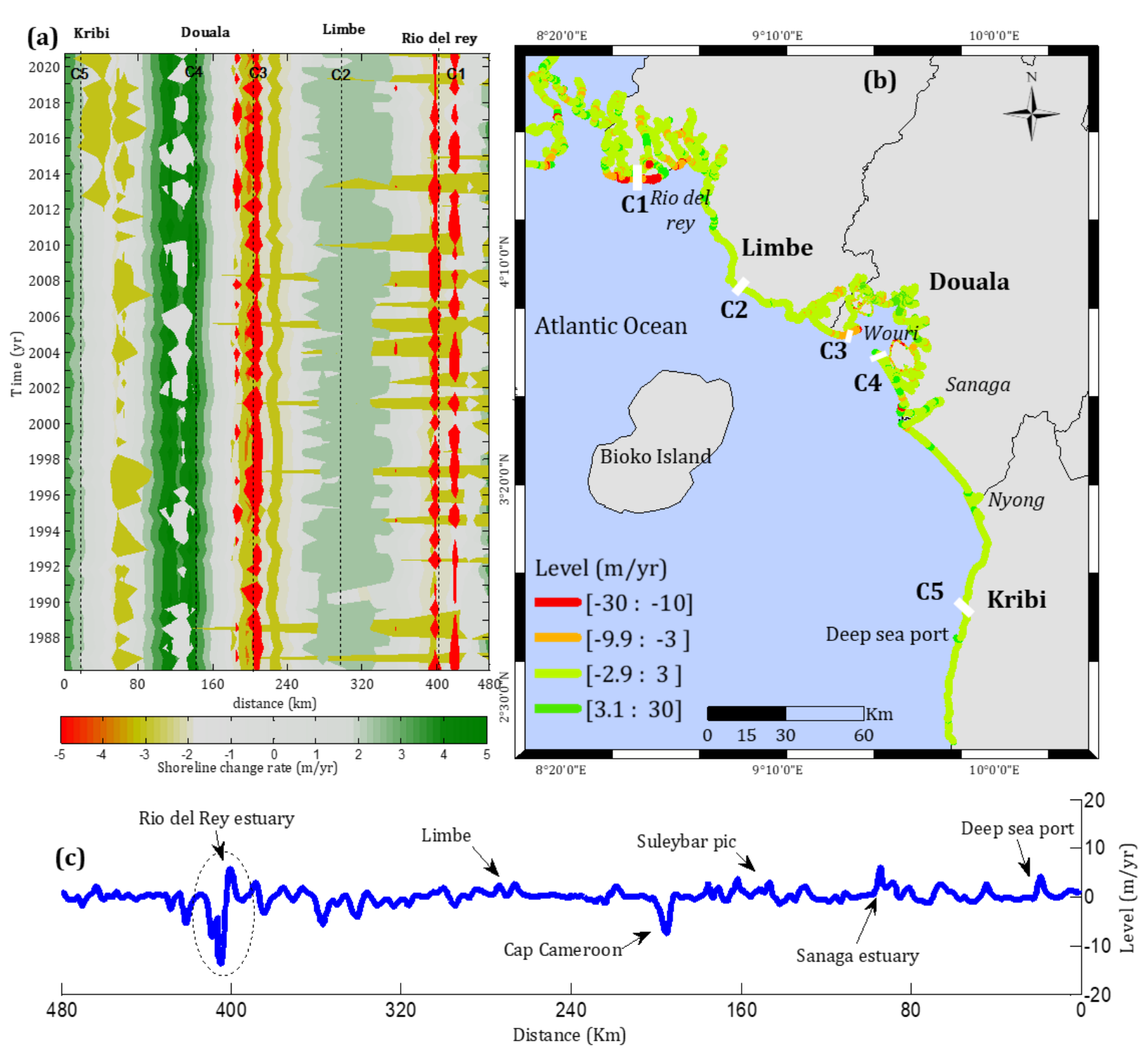

277 Figure 2 Map of spatio-temporal changes showing erosion/accretion evolution. (a)

278 Hovmoller diagram rate of change; (b) Overall coastline placement rate with sub-areas of

279 interest identified (transepts: white dash C1 to C5); (c) Net rate of shoreline change between

280 1986-2020 showing a linear velocity trend along the coastline.

281 Table 3 shows small changes (between 0.43 and $0.65 \mathrm{~m} /$ year) in the Kribi (C5) and

282 Limbé (C2) segment. Significant and very localised changes are observed with an erosion of $283-11$ to $-6 \mathrm{~m} /$ year respectively in $\mathrm{C} 1$ and C3. Section (see above on section, part, segment....) 
284 C4 is accumulating while parts C1 and C3 are heavily eroding. An illustration is made by the

285 diagram in figure 2a, which shows permanent erosion well before the year 1988.

286 Table 3: Area change and overall observed displacement rate by area of interest

\begin{tabular}{|c|c|c|c|c|c|}
\hline & $\begin{array}{l}\text { Kribi } \\
\text { (C5) }\end{array}$ & $\begin{array}{l}\text { Suleybar pic } \\
\text { (C4) }\end{array}$ & $\begin{array}{c}\text { Cap Cameroon } \\
\text { (C3) }\end{array}$ & $\begin{array}{l}\text { Limbe } \\
\text { (C2) }\end{array}$ & $\begin{array}{c}\text { Rio del rey } \\
\text { (C1) }\end{array}$ \\
\hline Surface $\left(\mathrm{km}^{2}\right)$ & 11.5 & 8.21 & 6.4 & 8.24 & 25.87 \\
\hline $\begin{array}{l}\text { Deplacement rate } \\
\text { (m/yr) }\end{array}$ & $0.65 \pm 0.04$ & $5.87 \pm 0.78$ & $-6.05 \pm 1.43$ & $0.43 \pm 0.05$ & $\begin{array}{c}-11.601 \pm \\
4.02\end{array}$ \\
\hline $\begin{array}{l}\text { Observation (1986- } \\
\text { 2020) }\end{array}$ & Stable & strong accretion & erosion & $\begin{array}{c}\text { weak } \\
\text { accretion }\end{array}$ & $\begin{array}{l}\text { strong } \\
\text { erosion }\end{array}$ \\
\hline & & & & & \\
\hline
\end{tabular}

290 To ground-truth satellite-based data, satellite-derived results were compared with 291 field data at C2 and C5 (Fig. 3). Data form other sections are not available. The comparison 292 indicates that the satellites are able to well identify the main horizontal coastline changes ( $\mathrm{r}$ $293=0.84$ for $\mathrm{C} 5$ and 0.79 for $\mathrm{C} 2$ ).
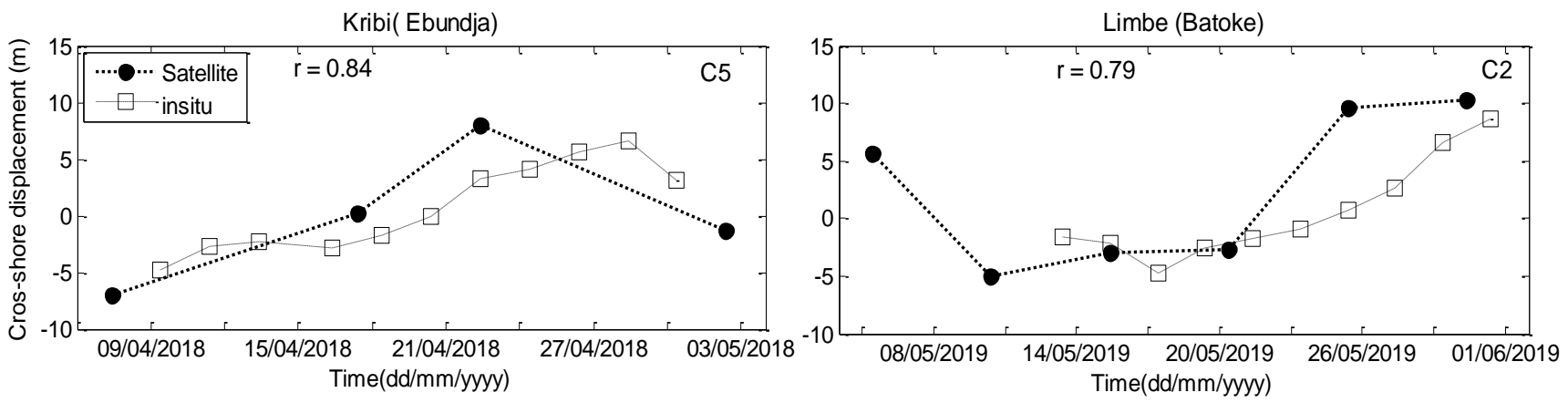

295 Figure 3: difference in across-shore displacement between in situ and satellite 296 measurements (Kribi C5 and Limbé C2). 


\subsection{Seasonal coastline variability and wave regime}

The results of the seasonal analysis of shoreline changes and waves are shown in Figure 4. It is noted that the seasonal variation of the shoreline presents two different phases, an accretion phase in winter (September to February) and an erosion phase in summer (March to August). During this later phase, the maximum erosion is reached in June except in C5 303 by summer waves with a significant monthly mean height between $1.2 \mathrm{~m}$ and $1.7 \mathrm{~m}$ 304 respectively in segments C1 and C5. Summer Hs are highest near C5 and lowest at C1 to C2 305 (northern part). It is during periods of high turbulence that significant erosional disturbance 306 of the shoreline is observed. Note that a delay is generally observed between high Hs values 307 and shoreline movement. During the winter (September to February), Hs values are almost 308 below the annual average in all segment. (Fig. 4).
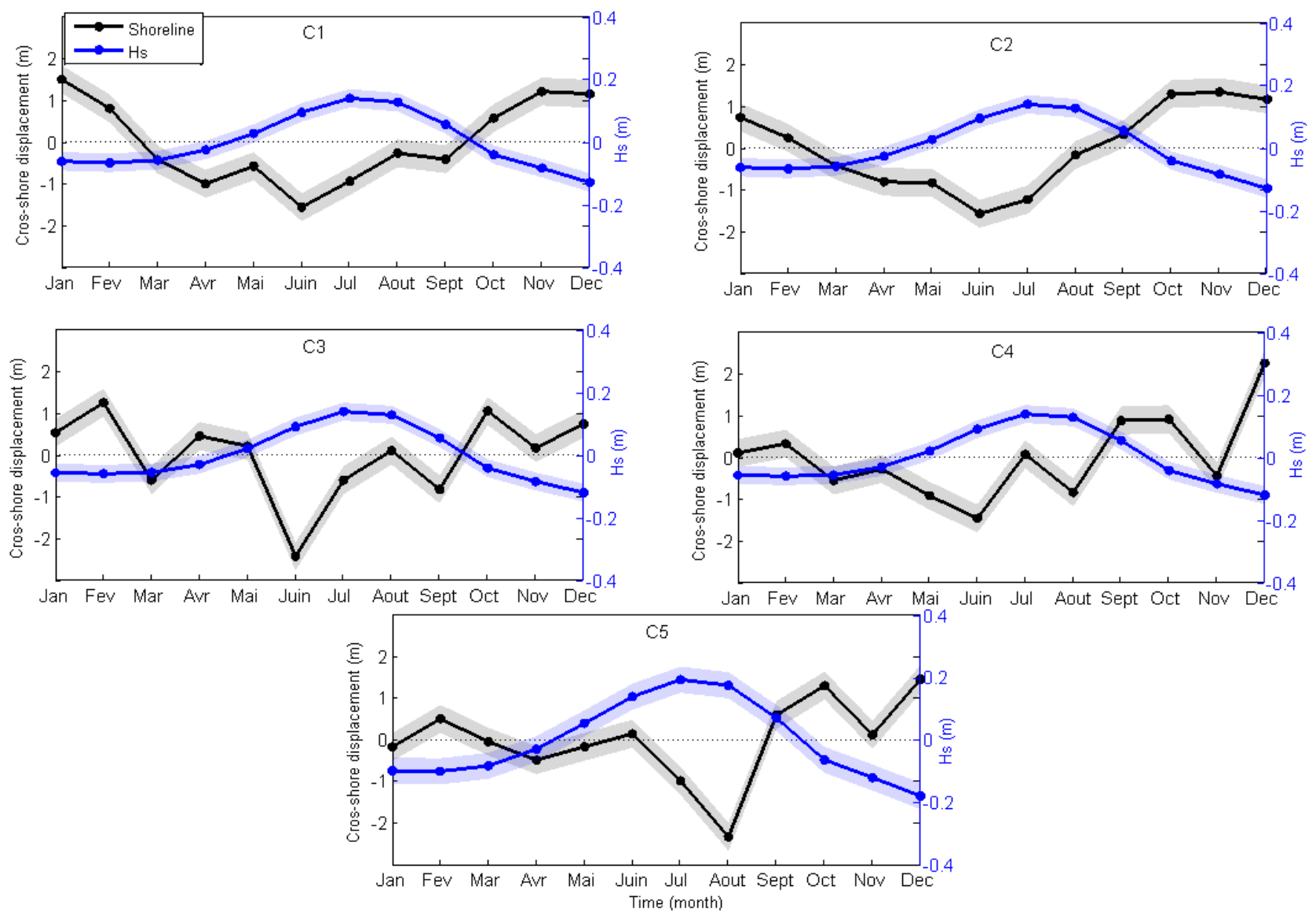
Figure 4: Monthly variation in coastline and waves by segment ( $\mathrm{C} 1$ to $\mathrm{C} 5$ ). Mean values and uncertainties ( \pm standard deviation) are shown. The monthly coastlines are derived from the processing of the 425 GEE archive images via the CoastSat Toolbox. The blue curve represents the monthly variation in wave height, while the black curve represents the monthly coastline changes during the period 1986-2020.

\section{5} 316

\subsection{Interannual coastline and wave height variability}

Interannual analyses (fig. 5) show significant fluctuations of the coastline from one year to another and from one site to another. The interannual evolution of the coastline shows three main periods of significant change from one segment to another. In segment $\mathrm{C} 1$, there was a marked retreat of the coastline during the first period (1986-1994), of the order of - $3 \pm 1.4$ m. Hs peaked in 1990 and subsequently declined with a trend of $-0.0047 \mathrm{~m} /$ year. Significant accretion shifts began to occur in the second period (1994 to 2005). In the final period the shoreline oscillated between erosion and accretion. In $\mathrm{C} 2$, the first two periods are marked by a regressive trend of the order of $-4 \pm 0.2 \mathrm{~m}$, followed by a period of accretion during the third period (2006-2020). Segment C3 is marked by a pronounced shoreline retreat of -9.4 $\pm 0.7 \mathrm{~m}$ over the $1986-1996$ period. As in C1, the second period shows an accretion trend of $0.8 \pm 0.0021 \mathrm{~m} /$ year, followed by a period of erosion (1994-2005). Segment C4 is relatively stable with time, marked by some punctual periods of erosion and accretion. In C5 a maximum interannual progradation of the coastline of $10 \pm 1.45 \mathrm{~m}$ was reached in 1989 followed by a long period of average stability of $0.76 \pm 1.3 \mathrm{~m}(1992-2007)$. A continuous regression of the order of $-5 \pm 0.23$ m was observed during the period 2008 to 2015 . Linear regression analysis for shoreline changes from 1986 to 2020 showed a general erosion trend of -6.2 m/year during the first period (1986-1994) and accretion trends during the second 

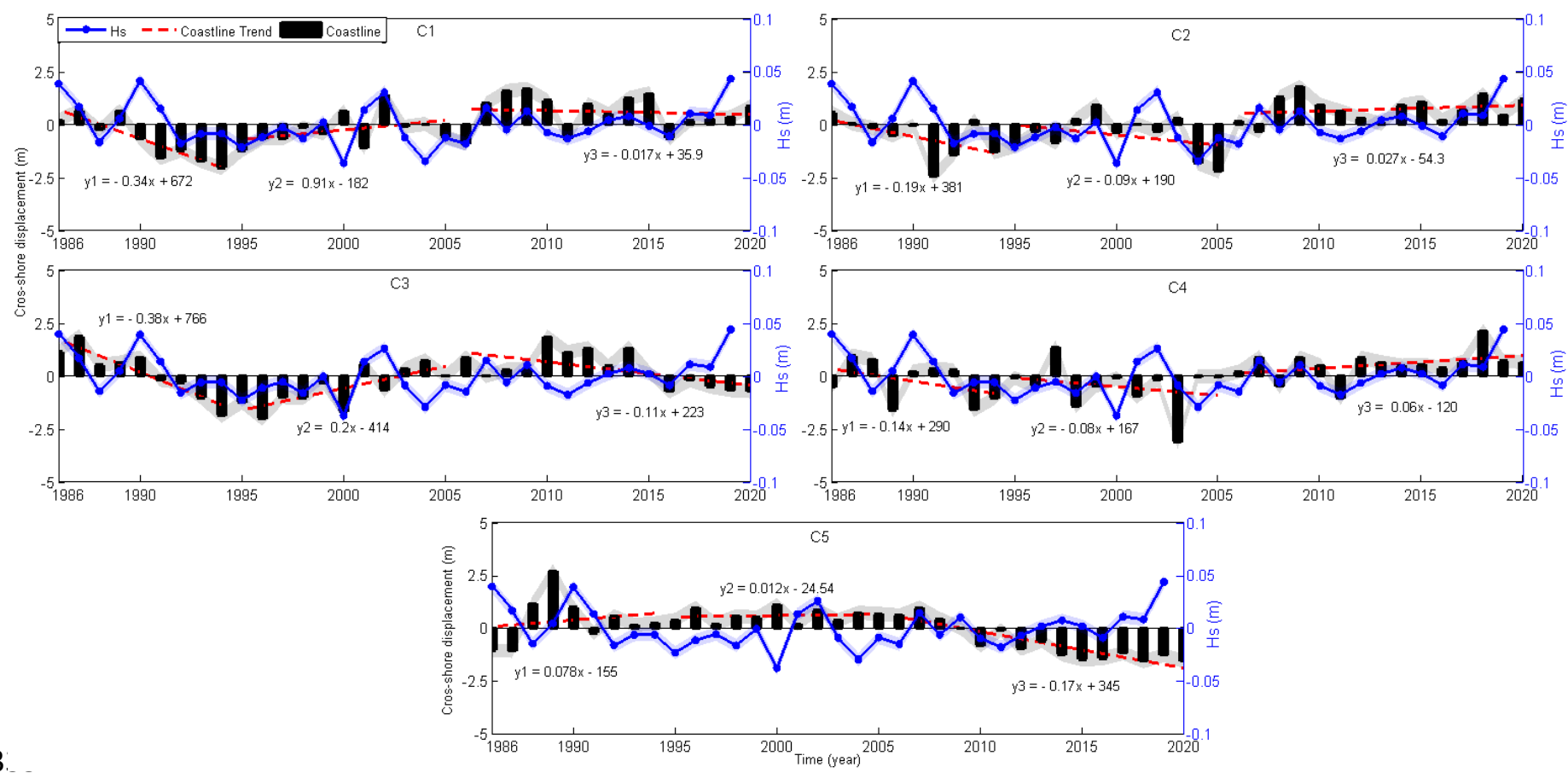

336 Figure 5. Interannual coastline and wave variability by segment (C1 to C5). The coastline trend is represented by the red line; uncertainties are also associated with the curves $( \pm$ standard deviation). These results are derived from the processing of the 425 GEE archive images via the CoastSat Toolbox.

The interannual variation of waves in each segment ( $\mathrm{C} 1$ to $\mathrm{C} 5$ ) shows a weak and constant wave climate distribution ( $\mathrm{Tp}=7$ to $12 \mathrm{~s}$ in S-SW direction), the annual mean of Hs varies from 0.7 to $1.7 \mathrm{~m}$ with maximum of $1.7 \pm 0.12 \mathrm{~mm}$ in $\mathrm{C}$. The interannual wave variability Fig 5 (C1-C5), shows an overall decrease in height during the first period of 1986 - 1994 with an annual downward trend at all segments (-0.0056 to $-0.0041 \mathrm{~m} /$ year). Despite a significant fluctuation observed between 1999-2001, the second period (1995 to 2005) is marked by a relative stability in wave heights (trend between 0.0002 and $0.0006 \mathrm{~m} / \mathrm{year}$ ) on the whole coast. The third period (2006 - 2019) is characterized by annual upward trends of Hs (0.0017 to $0.003 \mathrm{~m} /$ year) with an amplitude that increases towards the south (i.e. from 
349 segment C1 to C5). Distinct peaks characterized by values of Hs above the annual average as

350 shown in Figure 5 (C1 to C5), were observed in 1986, 1990, 2002 and 2019.

Interannual coastal changes were correlated to wave climates and the results are

352 shown on Table 4. The variability of wave climate is more correlated with the coastline 353 dynamics during the first period (1986-1994), with a correlation coefficient $r=0.5$ in 354 segments C1 to C4. While between 2005 and 2020, the wave regime could be responsible for 355 the erosion observed at C3 $(r=-0.65)$. Overall, these results indicate that waves do not fully 356 explain the high variability along the coastline. However, the involvement of waves makes it 357 possible to understand more than $40 \%$ of the coastline dynamics in certain segments.

358 Table 4: correlation coefficients between coastline and wave trend at interannual scale.

\begin{tabular}{cccccc}
\hline $\begin{array}{c}\text { Corrélation } \\
\Delta \text { X \& Hs }\end{array}$ & Kribi & $\begin{array}{c}\text { Suleybar pic } \\
\text { (C5) }\end{array}$ & $\begin{array}{c}\text { Cap Cameroon } \\
\text { (C4) }\end{array}$ & $\begin{array}{c}\text { Limbe } \\
\text { (C3) }\end{array}$ & $\begin{array}{c}\text { Rio del rey } \\
\text { (C2) }\end{array}$ \\
\hline $1986-1994$ & -0.42 & $\mathbf{0 . 5 2}$ & $\mathbf{0 . 5 2}$ & $\mathbf{0 . 5 1}$ & $\mathbf{0 . 5}$ \\
$1995-2005$ & 0.39 & -0.39 & 0.07 & 0.29 & 0.05 \\
$2005-2020$ & -0.42 & $\mathbf{0 . 5}$ & $\mathbf{- 0 . 6 5}$ & 0.35 & -0.32 \\
\hline
\end{tabular}

\subsection{Spatial and temporal patterns in shoreline variability}

An analysis of localized variability shows a dis-proportionality from one area to another. 368 northern part was slightly eroded, followed by a second period (2013-2019) with a 
migration and enlargement of the eroded zone and a concentration of an accumulation zone further south (Fig. 6a and Fig. 2 a and b).

Zone C2, for its part, is characterized by relative overall stability, although accompanied by regressive instability during 1991 and 2004, a period during which maximum variations in wave height were observed.

Part C3 (Cape Cameroon) experienced regressive coastline migration for nearly two decades (1986 - 2004). The variations observed in C3 during the 1986 - 2004 period were accompanied by strong wave activity $(1.35 \pm 0.4 \mathrm{~m})$, creating a significant trend in cumulative erosion estimated at around $-10 \mathrm{~m} /$ year. A different dynamic emerges from 2007, characterized by a permanent stability until the end of the study. Less significant and almost uniform variations are observed in C4, with a progressive formation of a sandy spit. 380 The seasonal wave signal, although weak and permanent, is consistent with these slow 381 changes (Fig. 4 - C4).

To examine causal factors for spatial and temporal variations in more detail, an analysis of the empirical orthogonal function (EOF) of the generated shoreline change and wave data was performed. The EOF analysis results show two modes (Fig. 6a) in each segment. Mode 1 accounts for $76.3 \%$ of the variability and mode 2 explains $23.7 \%$ of the variability. Based on a similar study carried out in the Bight of Benin in West Africa (Anthony et al., 2019), mode 1 may be related to small scales associated with relatively pronounced local erosion/accretion changes caused by natural shoreline dynamics, low angle of wave incidence at the point of surf $\left(5^{\circ}-10^{\circ}\right)$ but also the presence of protective structures. Mode 2 can be interpreted as representing a larger scale associated with the progressive decrease in accretion from south to north over the study period (Fig. 6b), highlighting the influence of regional-scale waves on coastline dynamics. 


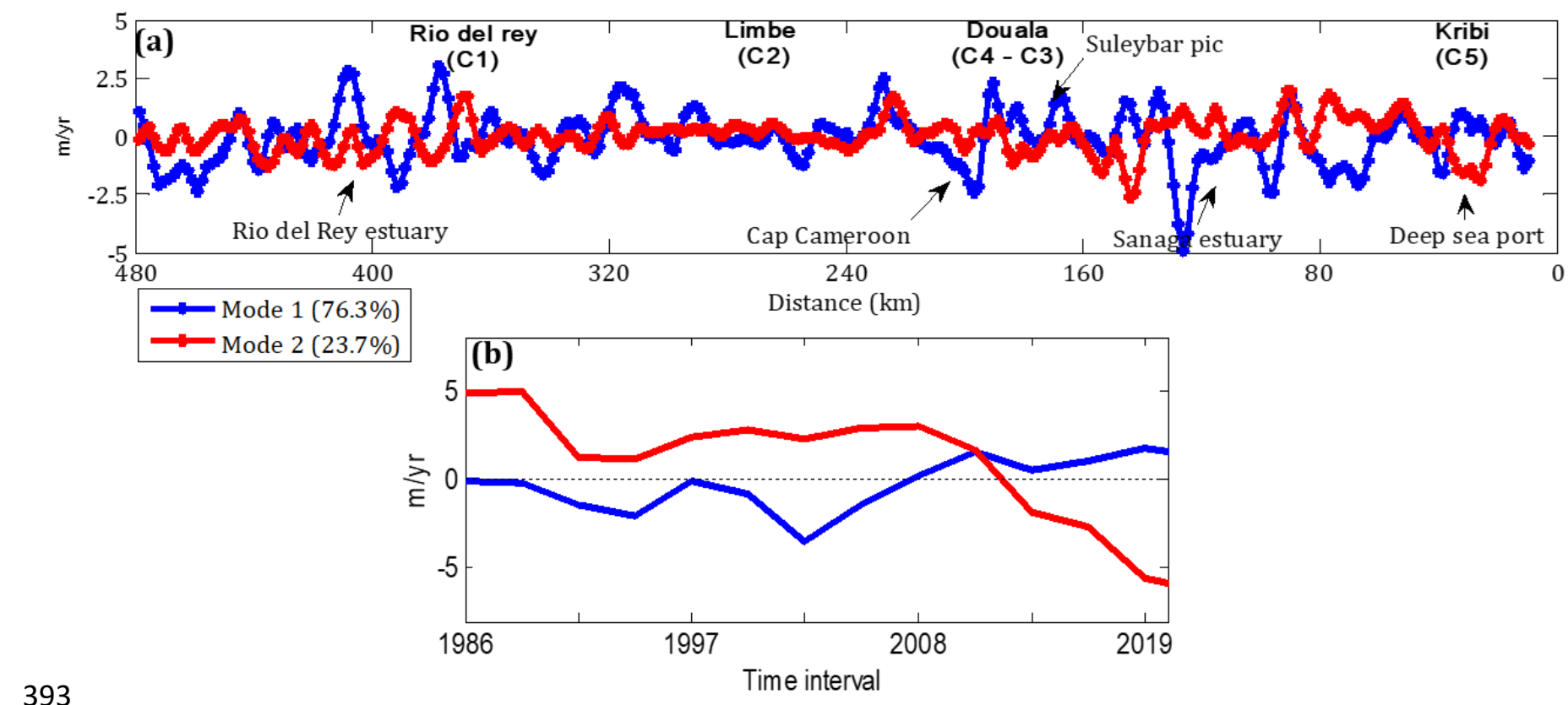

Figure 6 Maps of contributions to shoreline change: (a) Spatial mode EOF (mode1: 76.3\% of total variance) and EOF2 (mode2: $23.7 \%$ of total variance); (b) Temporal mode expressing the temporal behaviour of the rate of change.

\section{Discussion}

The decadal-scale analyses of changes of the Cameroonian coastline between 1986 and 2020 reveals on one hand a complex and segmented spatial configuration in five areas (C1 to C5) and on the other hand three temporal phases characterized by a significant fluctuation of the coastline with considerable variability between segments.

Estuaries are characterised by often complex dynamics as a result of interactions of river flow, waves, tides and coastal drift (Anthony et al., 2019; Abessolo et al., 2018; Dada et al., 2016). The strong erosion trends during the first period (1986-1994) in segments C1 and C3 are chiefly attributable to the cutting of mangroves amplified by an increase in sea level, and a resulting reduction in absorbtion of wave energy reaching the coast (Onguéné et al., 2015). Dada et al (2015) noted that shoreline retreat from the Niger Delta coastline, at a rate of 28 m/year, between 1950 and 1987 were mainly related to negative anomalies in rainfall 
and river flows due to climate change. In addition, recent studies (e.g. Almar et al, 2015 ; Dada et al., 2015; Kuenzer et al., 2014; Obowu and Abam, 2014; Adegoke et al., 2010) have suggested that the current coastline in West Africa alternates between erosion and accretion. Almar et al, 2015 demonstrated that this can be attributed to two distinct and simultaneous processes: first order, the decrease in southwest swells generated by storms at mid-latitudes and, second order, the increasing contribution of secondary swells southeast (which will cause coastal transport to the west, thereby reducing net coastal transport to the east) generated by positive trade anomalies. However, it remains difficult to infer that the same processes affect the Cameroonian coast at the bottom of the bay of Bonny.

The overall coastline displacement rate shows strong variations at the estuaries entrances (C1 and C3), as might be expected. A source of error could be due to the acquisition time of image-derived estuarine shorelines as the position of the sandbank depends on the seasonal variability of river runoff and oceanic forcings (Onguéné, 2015). However, cameroonian estuaries are characterized by the high flows of the Rio del rey rivers (C1), the Wouri estuary, one of the largest in the sub-region (C3 and C4), and the Sanaga river (Fig 2). These regions have been identified as the main hot spots on the Cameroonian coast (Abessolo et al., 2018, Fossi et al., 2019). And the coastal currents in these estuaries have been identified as responsible for the variability in sediment inputs that affect not only the dynamics of the coastline but also seasonal sediment transport. For example, the eroded area of Cape Cameroon (C3) corresponds to the current flowing out of the estuary. Major port works or protection works, located on a coast affected by a predominantly coastal transit, also disturb the balance of sediment transport, by blocking the materials on the "fed" face of the structures, they cause erosion under the "undernourished" face.

Segments C2 and C4 (Limbé and Pointe de Souleyba) are characterized by moderate to significant accretion rates of $2.4 \mathrm{~m} /$ year and $18.5 \mathrm{~m} /$ year, dominated by natural shoreline 
modification patterns, such as the Souleyba spit (C4) which is relatively recent feature. Abessolo et al. (2018) demonstrated that the convergence of the flows of the Wouri andthe Dibamba River associated with the littoral drift contribute to the accumulation of sediments observed at Souleyba (C4).. It is interesting to note that even if C4 integrates the shore opposite to C3 in the mouth of the Wouri River, this side of the estuary corresponds to the main source of sand supply from the shore in the estuary: the advance estimated at 69 $\mathrm{m} /$ year in this sector was observed in the period 2010-2019 (Figure 3) and corresponds to a convergence of sediments eroded on the southwestern part of Manoka Island and those sourced from the ocean. The rate of change of coastline displacement remains relatively stable in section $\mathrm{C} 2$, as the lithological nature is characterized by the presence of cohesive sediments and rocky coasts as well as a coast dominated by the presence of mangroves and vegetation that absorb wave energy, which are otherwise very low in density in this segment. In the southern part C5, an abrupt change in dynamics is observed as of late 2012, likely due to the construction of a $1.5 \mathrm{~km}$ offshore oriented dike at the port of Kribi $(30 \mathrm{~km}$ to the south of Kribi) in late 2012. The amount of sediment bypassing the dike may not sufficient to balance the high transport potential in this area (Fig. 2a, b). A number of quarries for extracting beach sand for construction purposes are located in the area, from which a volume of more than $45,000 \mathrm{~m} 3 /$ year of sediment is extracted over the entire Kribi coastal strip (MINEPDED, 2017). The distance from the baseline (reference shoreline) shows fluctuating displacements $\pm 10 \mathrm{~m}$, especially between 2005 and 2020 (Fig. 2a). Such an alteration (with human intervention) of the balance between sediment input and coastal erosion leads to a progressive degradation of the coastal system (Rovira and Ibàñez, 2007; Batalla et al., 2004; Sanchez-Arcilla et al., 1998).

The interannual wave variability obtained in the present study shows a gradual increase in Hs since 1990. The order of magnitude of the increasing trends in mean Hs 
( 0.0017 to $0.003 \mathrm{~m} /$ year; Figure 5) found in the present study, particularly between 2005 and 2020, are in line with the results of many studies carried out in the Gulf of Guinea subregion. Several ocean wave studies have reported an increase in Hs in the North Atlantic Ocean in recent decades (e.g. Bertin et al., 2013; Le Cozannet et al., 2011; Dodet et al., 2010). Bertin et al. (2013) observed an increase in Hs over the entire North Atlantic Ocean based on numerical analysis of retrospective winds (1900 to 2008), reaching $0.01 \mathrm{~m} / \mathrm{yr}$ and gradually decreasing to less than $0.005 \mathrm{~m} / \mathrm{yr}$ in the southern North Atlantic. The results obtained by Dada et al, 2016 in the coast of the Niger Delta (upper limit of Bonny Bay), are slightly larger but of the same order of magnitude as that obtained in our study. This could be explained by the fact that the work of Dada et al. 2016 was calculated over a much longer period (last 110 years) with a maximum increase in $\mathrm{Hs}$ of $0.0054 \mathrm{~m} /$ year. The seasonal rhythm of the coastline indicates a period of erosion corresponding to the passage of the ITCZ over the equatorial zone characterized by heavy rainfall. During this period of heavy agitation (May to September), wave heights increase and the coast undergoes significant disturbance. Almar et al. in 2015 demonstrated that the equatorial fluctuation of the Intertropical Convergence Zone (ITCZ) explains most of the variability in wave-induced transport but also the predominant influence of the Southern Annular Mode (SAM) on waveinduced transport.

The results of the analysis of EOF variability patterns of spatial-temporal shoreline 478 changes show two modes. The first represents the relatively marked local influence of 479 natural dynamics such as waves, drift currents and river flows at C1 (Rio del rey), C2 and C3 480 (Wouri estuary) and along the coasts with the presence of coastal infrastructures, such as at 481 C5 (Fig 6a). The second mode represents larger scale changes. These results mainly show 482 that the changes on this coast are due to several factors, and that the wave regime acts in 483 combination with several other factors at the local and regional level. 
484 5. Conclusion

485

The evolution of the coastline based on a 34-year time series (1986 to 2020) of satellite image data (Earth Explorer and GEE) and the Era-interim re-analysed wave data improved the understanding of coastline variability and local and regional wave climate in the study area. The shoreline change analysis undertaken here reveals a permanent and localized erosive trend on two segments ( $\mathrm{C} 1$ and C3) over the $402 \mathrm{~km}$ along the Cameroonian coast. Nevertheless, a seasonal signal on coastline variability is evident, corroborated by the strong interannual variability in local and regional wave climate. The EOF analysis has highlighted two modes of variability representing respectively the local spatiotemporal scale influence mode 1 , but also a larger scale influence mode 2 . While this study suggets that shoreline changes are strongly related to local and regional wave climate variability, it is important to note that shoreline stability is also strongly dependent on a constant supply of sediments, and other processes such as: variability of river flows in drift currents, and anthropogenic effects, may act in combination with changes in wave regime and resulting coastal transport to influence shoreline changes along the Cameroonian coast.

\section{Acknowledgements}

500 This project was funded by the service de coopération et d'Action Culturelle (SCAC) of the 501 French Embassy in Cameroon within the framework of a research mobility grant awarded to 502 Njutapvoui Nourdi, as part of a co-supervision agreement between the University of Douala 503 (UDo_EDSFA) and the University Paris Est Marne la Vallée. We used data provided though 504 the ECMWF ERA Interim dataset (www.ECMWF.Int/research/Era), Landsat images 505 downloaded from earthexplorer.usgs.gov, Google Earth Engine (GEE) and Sentinel images 506 from the ESA Copernicus program (https://scihub.copernicus.eu/dhus/). 
508

509

510

511

512

15

Abessolo Ondoa, G.; Onguéné, R.; Tomedi Eyango, M.; Duhaut, T.; Mama, C.; Angnuureng, B.D., and Almar, R., 2018. Assessment of the evolution of Cameroon coastline: An overview from 1986 to 2015. In: Tropical Coastal and Estuarine Dynamics. Journal of Coastal Research, Special Issue, No. 81, pp. 122-129. Coconut Creek (Florida), ISSN 0749-0208.

Adams, P.N., Inman, D.L., Lovering, J.L., 2011. Effects of climate change and wave direction on longshore sediment transport patterns in Southern California. Clim. Chang. 109, 211-228.

Adegoke, J.O., Fageja, M., Godstime, J., Agbaje, G., Ologunorisa, T.E., 2010. An assessment of recent changes in the Niger Delta coastline using satellite imagery. J. Sustain. Dev. 3(4), 277-296.

517 Ajonina, G.N., 2010. Rapport final de réalisation du mandat. Consultation Project GEF PPG, 36 .

Almar, R.; Honkonnou, N.; Anthony, E.J.; Castelle, B.; Senechal, N.; Laibi, R.; Mensah-Senoo, T.; Degbe, G.; Quenum, M.; Dorel, M.; Chuchla, R.; Lefebvre, J. P.; Du Penhoat, Y.; Laryea, W. S.; Zodehougan, G.; Sohou, Z.; Addo, K.A.; Ibaceta, R., and Kestenare, E., 2014. The Grand Popo beach 2013 experiment, Benin, West Africa: From short timescale processes to their integrated impact over long-term coastal evolution. In: Green, A.N. and Cooper, J.A.G. (eds), Proceedings 13th International Coastal Symposium (Durban, South Africa). Journal of Coastal Research, Special Issue No. 70, pp. 651-656.

Almar, R.; Kestenare, E.; Reyns, J.; Jouanno, J.; Anthony, E.J.; Laibi, R.; Hemer, M.; Du Penhoat, Y., and Ranasinghe, R., 2015. Response of the Bight of Benin (Gulf of Guinea, West Africa) coastline to anthropogenic and natural forcing, Part1: Wave climate variability and impacts on the longshore sediment transport. Continental Shelf Research, 110, 48-59.

Angnuureng, D. B., R. Almar, K. Appeaning Addo, N. Senechal, B. 438 Castelle, S.W. Laryea, and G. Wiafe, 2016: Video observation of waves and shoreline change on the microtidal 
James town Beach in Ghana. Journal of Coastal Research, Proceedings of the 14th International Coastal Symposium, Sydney, Australia, Special Issue 75, 1022 - 1026, ISSN 0749-0208.

Anthony .E.J., R. Almar., M. Besset., J. Reyns., R. Laibi., R. Ranasinghe., G. Abessolo Ondoa., M. Vacchi; 2019 : Response of the Bight of Benin (Gulf of Guinea, West Africa) coastline to anthropogenic and natural forcing, Part 2: Sources and patterns of sediment supply, sediment cells, and recent shoreline change. Continental Shelf Research 173 (2019) 93103 (https://doi.org/10.1016/i.csr.2018.12.006)

Anthony, E.J., 2017. Beach erosion. In: Finkl, C., Makowski, C. (Eds.), Encyclopedia of Coastal Science. Encyclopedia of Earth Sciences Series. Springer, Cham.

Batalla, R.J., Gomez, C.M., Kondolf G. M., 2004. Reservoir-induced hydrological changes in the Ebro River basin (NE Spain). J. Hydrol. 290, 117-136.

Battjes, J.A.; Janssen, J.P.F.M. Energy loss and setup due to breaking of random waves. In Proceedings of the ASCE International Conference on Coastal Engineering, Hamburg, Germany, 27 August-3 September 1978; pp. 569-587.

Bertin, X., Prouteau, E., Letetrel, C., 2013. A significant increase inwave height in the North Atlantic Ocean over the 20th century. Glob. Planet. Chang. 106, 77.

Boateng, I., 2009. Development of integrated shoreline management planning: A case study of keta, Ghana. TS 4E-Coastal Zone Management. FIG Working Week 2009. Surveyors Key Role in Accelerated Development Eilat, Israel, 3-8 May 2009.

Boateng, I., 2012. An application of GIS and coastal geomorphology for large scale assessment of coastal erosion and management: a case study of Ghana. J. Coast. Conserv. (16), 383397. http://dx.doi.org/10.1007/s11852-012-0209-0. 
Bosom, E. and Jiménez, J.A., 2011. Probabilistic coastal vulnerability assessment to storms at regional scale - application to Catalan beaches (NW Mediterranean). Natural Hazards and Earth System Science, 11, 475-484.

Caires S, Swail VR, Wang XL., 2006 Projection and analysis of extreme wave climate. J Clim 19:5581-5605

Dada, O.A., Qiao, L.L., Ding, D., Li, G.X., Ma, Y.Y., Wang, L.M., 2015. Evolutionary trends of the Niger Delta Shoreline during the last 100 years: responses to rainfall and river discharge. Mar. Geol. 367, 202-211. http://dx.doi.org/10.1016/i.margeo.2015.06.007.

Dada, O. A., Li, G., Qiao, L., Ma, Y., Ding, D., Xu, J., ... Yang, J. (2016). Response of waves and coastline evolution to climate variability off the Niger Delta coast during the past 110years. Journal of Marine Systems, 160, 64-80. doi:10.1016/j.jmarsys.2016.04.005

Dee, D.P.; Uppala, S.M.; Simmons, A.J.; Berrisford, P.; Poli, P.; Kobayashi, S.; Andrae, U.; Balmaseda, M.A.; Balsamo, G.; Bauer, P.; Bechtold, P.; Beljaars, A.; Van De Berg, L.; Bidlot,J.R.; Bormann, N.; Delsol, C.; Dragani, R.; Fuentes, M.; Geer, AJ.; Haimberger, L.; Healy, S.; Hersbach, H.; Hólm, E.V.; Isaksen, L.; Kållberg, P.W.; Köhler, M.; Matricardi, M.; McNally, A.; Monge-Sanz, B.M.; Morcrette, J.J.; Peubey, C.; De Rosnay, P.; Tavolato, C.; Thépaut, J.N., and Vitart, F., 2011. The ERA-Interim reanalysis: Configuration and performance of the data assimilation system. Quarterly Journal of the Royal Meteorological Society, 137(656), 553-597.

Dodet, G., Bertin, X., Taborda, R., 2010.Wave climate variability in the North East Atlantic over the last 6 decades. Ocean Model. 31, 120-131

Faye, I.B.N., 2010. Dynamique du trait de côte sur les littoraux sableux de la Mauritanie à la Guinée-Bissau (Afrique de l'Ouest) : Approches régionale et locale par photointerprétation, traitement d'images et analyse de cartes anciennes ». Volume 1, thèse de doctorat, Géographie, Université de Bretagne Occidentale, 321p. 
Fernand Verger, Raymond Ghirardi et al., 2002 L'espace nouveau territoire: Atlas des satellites et des politiques spatiales, Paris, Belin, 383 p. (ISBN $\underline{978-2-701-13194-8}$ et $\underline{2-}$

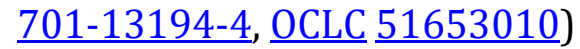

Fotsi, Pouvreau, Brenon, Onguene, \& Etame. (2019). Temporal (1948-2012) and Dynamic Evolution of the Wouri Estuary Coastline within the Gulf of Guinea. Journal of Marine Science and Engineering, 7(10), 343. doi:10.3390/jmse7100343

Giardino, A., Schrijvershofa, R., Nederhoffa, C.M., de Vroega, H., Brièrea, C., Tonnona, P.-K., Cairesa, S., Walstraa, D.J., Sosac, J., van Versevelda, W., Schellekensa, J., Sloffa, C.J., 2018. A quantitative assessment of human interventions and climate change on the West African sediment budget. Ocean Coast. Manag. 156, 249-265.

Giresse, P.; Megope, F.J.; Ngueutchoua, G., and Aloisi, J.C.,1996. Carte Sédimentologique du Plateau Continental du Cameroun. Paris, France: ORSTOM, Collection Notice Explicative $N^{\circ}$ $111,12 \mathrm{p}$.

Hapke, C.J., Himmelstoss, E.A., Kratzmann, M., List, J.H., Thieler, E.R., 2010. National assessment of shoreline change: Historical shoreline change along the New England and Mid-Atlantic coasts: US Geological Survey Open-File Report 2010-1118. p. 57.

Kuenzer, C., van Beijma, S., Gessner, U., Dech, S., 2014. Land surface dynamics and environmental challenges of the Niger Delta, Africa: remote sensing-based analyses spanning three decades (1986-2013). Appl. Geogr. 53, 354-368.

Laibi, R.A., Anthony, E.J., Almar, N., Castelle, B., Sénéchal, Kestenare, E., 2014. Longshore drift cell development on the human-impacted Bight of Benin sand barrier coast, West Africa. J. Coast. Res. (Special 70), pp.78-83.

Larson M, Hoan L, Hanson H. 2010 Direct formula to compute wave height and angle at incipient breaking. J Waterway Port Coast Ocean Eng 136:119-122 
Le Cozannet, G., Lecacheux, S., Delvallee, E., Desramaut, N., Oliveros, C., Pedreros, R., 2011. Teleconnection pattern influence on sea-wave climate in the Bay of Biscay. J. Clim. 24 (3), $641-652$.

Luijendijk, A., Hagenaars, G., Ranasinghe, R., Baart, F., Donchyts, G., Aarninkhof, S., 2018. The state of the world's beaches. Sci. Rep. 1-11. https://doi.org/10.1038/s41 598-01824630-6.

Longuet-Higgins, M.S., 1970. Longshore currents generated by obliquely incident sea waves: 1. J. Geophys. Res. 75, 6778-6789. http://dx.doi.org/10.1029/JC075i033p06778.

Melet, A.; Almar, R., and Meyssignac, B., 2016. What dominates sea level at the coast: A case study for the Gulf of Guinea. Ocean Dynamics, 66, 623-636.

Melet, A., B. Meyssignac, R. Almar, and G. Le Cozannet, 2018: Under-estimated wave contribution to coastal sea-level rise. Nature Climate Change, https://doi.org/10.1038/s41558-018-0088-y.

MINEPDED-RCM, 2017: Etat des lieux des mangroves du Cameroun. Ministère de l'Environnement, de la Protection de la Nature et du Développement Durable en collaboration avec le Réseau Camerounais des Mangroves. P.10-11. Juin 2017

Moore L. J., Griggs G.B. 2002 Long-term cliff retreat and erosion hotspots along the central shores of the Monterey Bay National Marine Sanctuary. Marine Geology, vol. 181, n¹-3, p. $265-283$.

623 Obowu, C.D., Abam, T.K.S., 2014. Spatial and multi-temporal change analysis of the Niger 624 Delta coastline using remote sensing and geographic information system (GIS). Int. J. $625 \quad$ Remote Sensing Appl. 4 (1), 41-47. 626 ONEQUIP, 2009 - Contrat $N^{\circ} 01090031$ relatif à l'élaboration d'un programme de suivi de la 627 vitalité des mangroves camerounaises. Projet CAPECE-CPSP/SNH. Rapport final, 146p. 
Onguéné, R., 2015. Modélisation Multi-Echelles de la Circulation Océanique en Afrique Centrale, de la Plaine Abyssale à l'Estuaire du Cameroun. Toulouse, France: University of Toulouse III Paul Sabatier, Ph.D. dissertation, 216p.

Onguene, R., et al. (2015) Overview of Tide Characteristics in Cameroon Coastal Areas Using Recent Observations. Open Journal of Marine Science, 5, 81-98. http://dx.doi.org/10.4236/ojms.2015.51008

Pilkey, O.H., Cooper, J.A.G., 2014. Are natural beaches facing extinction? J. Coast. Res. 70, 7883.

Ranasinghe, R., 2016. Assessing climate change impacts on open sandy coasts: A review, Earth-Science Reviews, 160, 320-332, doi:10.1016/j.earscirev.2016.07.011.

Richards, J. and Nicholls, R.J., 2009. Impacts of Climate Change in Coastal Systems in Europe. PESETA Coastal Systems study. Luxembourg: European Commission, Joint Research Center. JRC Scientific and Technical Reports, JRC 55390, EUR 24130 EN.

Rovira, A., Ibàñez, C., 2007.Sediment management options for the lower Ebro River and its Delta. J. Soils Sediment. 7(5), 285-295.

Robin, M., 2002. Télédétection et modélisation du trait de côte et de sa cinématique. In (Baron-Yelles N. Goeldner-Gionella L., Velut S., Ed.) Le littoral, regards, pratiques et savoirs. Etudes offertes à Fernand VERGER. Edition Rue d'Ulm / Presses universitaires de l'Ecole Normale Supérieure, Paris, p. 95 - 115.

Sanchez-Arcilla, A., Jimenez, J. A., Valdemoro, H. I., 1998. The Ebro Delta: morphodynamics and vulnerability. J. Coast. Res. 14(3), 754-772.

Stafford D.B., Langfelder J. 1971 Air photo survey of coastal erosion. Photogrammetric Engineering, vol. 37, p. 565 - 575.

Sterl, A. and Caires, S., 2005. Climatology, variability and extrema of ocean waves- the webbased KNMI/ERA-40 wave atlas. International Journal of Climatolology, 25, 963-977. 
653 Tano, R.A.; Aman, A.; Kouadio, K.Y.; Toualy, E.; Ali, K.E., and Assamoi, P., 2016. Assessment of the Ivorian Coastal Vulnerability. Journal of Coastal Research, 32(6), 1495- 1503

Thieler, E.R., Himmelstoss, E.A., Zichichi, J.L., Ergul, A., 2009. The Digital Shoreline Analysis System (DSAS) version 4.0an ArcGIS Extension for Calculating Shoreline Change. Available at: 〈http://woodshole.er.usgs.gov/project-pages/DSAS/version4/index.html〉. 658 Van der Walt, S., Scheonberger, J.L., Nunez-Iglesias, J., Boulogne, F., Warner, J.D., Yager, N., 659 Gouillart, E., Yu, T., 2014. scikit-image : image processing in Python. PeerJ 2, e453. 660 https://doi.org/10.7717/peerj.453.

661 Vos, K., Splinter, K. D., Harley, M. D., Simmons, J. A., \& Turner, I. L. (2019). CoastSat: A Google 662 Earth Engine-enabled Python toolkit to extract shorelines from publicly available satellite 663 imagery. Environmental Modelling $\&$ Software, 664 104528. doi:10.1016/j.envsoft.2019.104528

665 Vos, K., Harley, M.D., Splinter, K.D., Simmons, J.A., Turner, I.L., 2019. Sub-annual to multi666 decadal shoreline variability from publicly available satellite imagery. Coast. Eng. 150, 667 160-174. https://doi.org/10.1016/i.coastaleng.2019.04.004.

668 https://earthexplorer.usgs.gov/

669 https://scihub.copernicus.eu/dhus/

670 https://apps.ecmwf.int/datasets/data/interim-full-daily/ 
Conflicts of Interest: The authors declare no conflict of interest.

Conflict of Interest

Conflicts of Interest: The authors declare no conflict of interest.

Conflict of Interest

$\ldots$

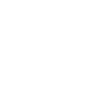

Conflicts of Interest: The authors declare no conflict of interest.

Conflicts of Interest: The authors declare no conflict of interest.

$-$

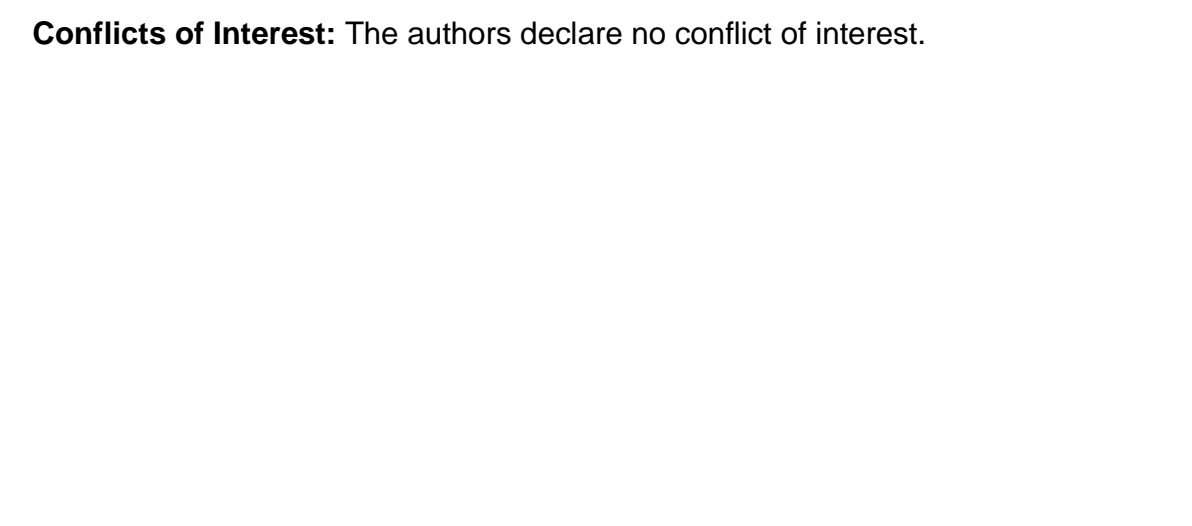

Conflicts of Interest: The authors declare no conflict of interest.

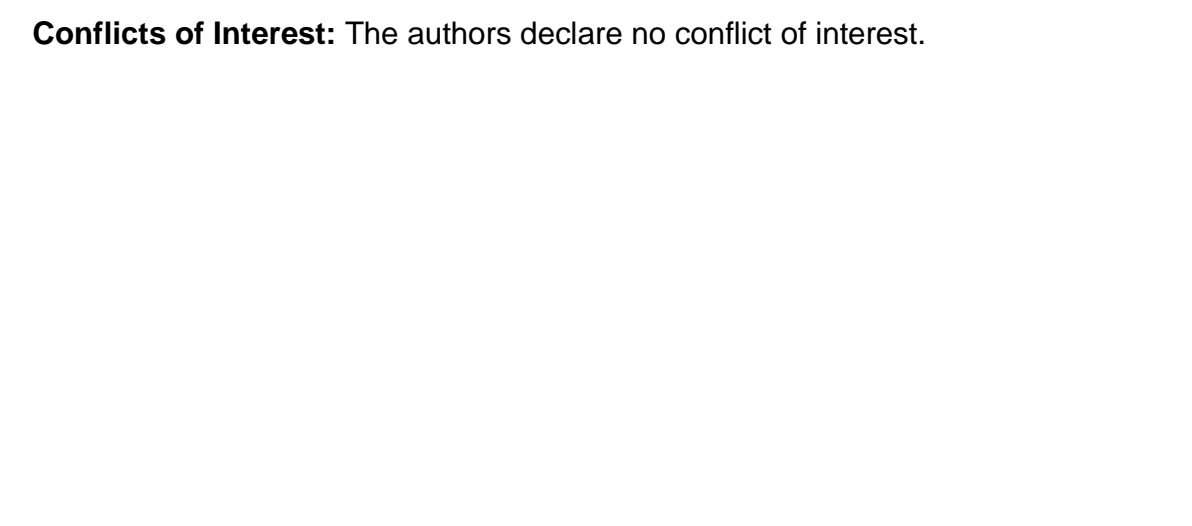

Conflicts of Interest: The authors declare no conflict of interest.

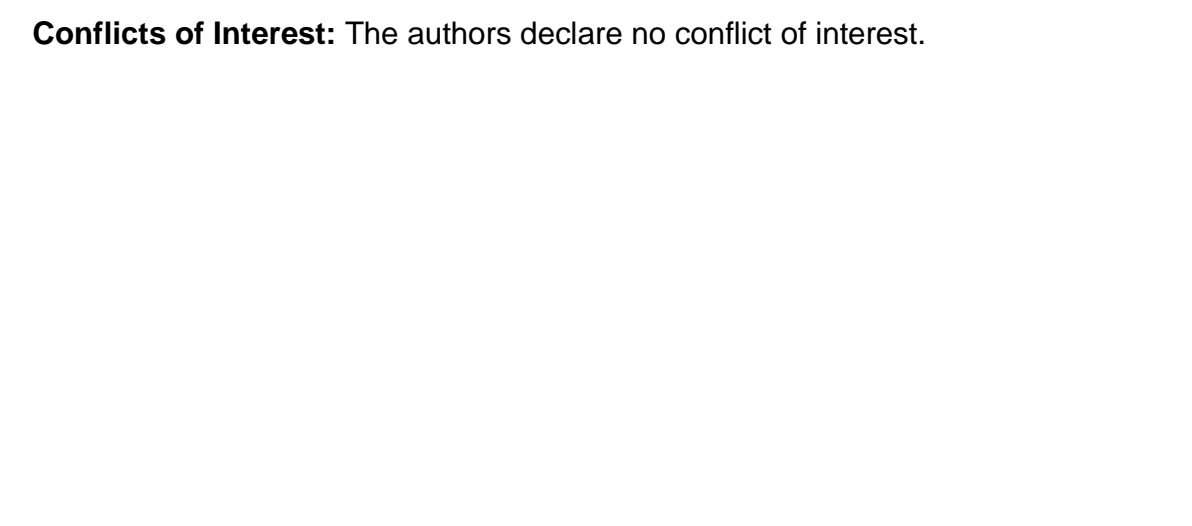

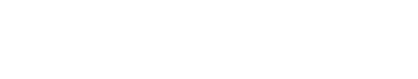

Conflicts of Interest: The authors declare no conflict of interest.
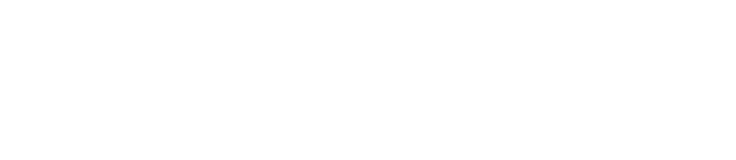

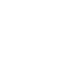

